\title{
Alternatives to the University Property Tax Exemption
}

\author{
State statutes ${ }^{1}$ and constitutions ${ }^{2}$ exempt from local property taxa- \\ tion all land and buildings of private colleges or universities used for \\ "educational purposes." 3 The primary justification for this exemption
}

1. Al.sSKa Stat. $\$ 29.53 .020$ (1972); ARIZ. Rev. Stat. ANN. \$42-271 (1956); Cal. Rev. \& Tax. Code \$ 203 (West Supp. 1973); Colo. Rev. STAt. ANN. \$ 137-I-3(7) (1963); Conn. Gen. Stat. ANN. \$ 12.81 (1958); Del. Code AnN. tit. 9, \$ 8103 (1953); D.C. Code ENCYCL. ANN. $\$ \$ 29.602,47-811$ (1966); FLA. STAT. ANN. \$ 196.198 (1972); GA. CodE ANN. \$ 92-201 (1970); Hawail Rev. Stat. \$ $246-32$ (Supp. 1972); Idaho Code \$63-105L (Supp. 1972); Ill. AnN. STAT. ch. 120, $\$ 500.1$ (Smith-Hurd 1936); IND. ANN. STat. $\$ 64-201$ (Supp. 1972); Iow. Code ANN. \$ 427.1.9-11 (1971); Kan. Stat. ANN. \$ 79-201 (1969; Me. Rev. Stat. ANN. tit. 36, $\$ 652$ (1964); MD. ANN. CoDE art. 81, \& 9(e) (Supp. 1972); MASs. ANN. Laws ch. 59, 5 (1971); Mich. CoMp. Laws ANN. \$211.7 (1967); MinN. STat. ANN. \$272.02 (Supp. 1973); MIss. Code ANN. \$ 9697(d) (Supp. 1972); Mo. ANN. STAT. \$ 137.100 (Supp. 1973); Mont. Rev. Codes ANn. \$ 84.202 (1947); Neb. Rev. Stat. \$ 77-202 (1971); Nev. ReV. STat. \$ 361-105 (1957); N.H. REV. Stat. ANN. \$ 72:23 (1970); N.J. STAT. ANN. $\$ 54: 4 \cdot 3.6$ (Supp. 1972); N.Y. REAL Prop. TAX LAW \$ 42I(la) (McKinney 1972); N.C. Gen. Stat. \$ 105-278(4) (1972); N.D. CENT. CODE ANN. \$ 57-02-08 (1960); OHIo REV. CodE AnN. \$ 5709.07 (Page 1954); OKLA. Stat. ANN. tit. 18, \$550 (Supp. 1972); Ore. Rev. STAT. \$ 307.145 (1971); PA. STAT. ANN. tit. 72, \$ 4821 (1968); R.I. GEN. LAWS ANN. \$ $44-3-3$ (1970); S.C. CODE ANN. \$ 65-1522 (1962); S.D. CoNipILED LAWS ANN. \$ 10-4-13 (1967); Tenv. Code ANN. $\$ 67-502$ (Supp. 1972); Tex. Rev. Civ. Stat. art. 7150(1) (1960); Utail CODE ANN. $\$ 59-2.1$ (1953); VT. STAT. ANN. tit. 32, \$3802 (1970); VA. CoDE ANN. \$ $58-12$ (Supp. 1973); WASH. Rev. Code ANn. \$ 84.36 .050 (Supp. 1972); W. VA. Code ANN. \$11-39 (1966); Wis. Stat. ANN. \$ 70.11 (1969); Wyo. Stat. ANn. $\$ 39-10$ (1957).

2. In fourteen states the tax exemption is constitutionally guaranteed: ALA. CoNsT. art. $4, \$ 91$; ARk. Consr. art. 16, $\$ 5$; CAL. Const. art. 13, $\$ 1$ 1a; Colo. Const. art. $\mathrm{X}$, $\$ 5$; KY. Const. $\$ 170$; LA. Consr. art. 10, $\$ 4$; Mich. Const. art. 9, $\$ 4$; MinN. Const. art. 9, $\$ 1$; Mo. Consr. art. 10, $\$$; N.J. Consr. art. 8, $\$ 1, \$ 2$; N.M. Consr. art. VIII, $\$ 3$; N.D. Consr. art. 11, \$ 176; S.C. Const. art. 10, \$ 4; VA. Consr. art. 10, $\$ 6(4)$. In addition, ten state constitutions explicitly permit the legislature to exempt educational institutions and in each of these states the legislature has done so: ARIz. CoNST, art. 9, $\$ 2$; Flt. Const. art. 7, $\$ 3($ a); GA. Consr. art. VII, $\$ 2-5404$; ILL. Const. art. 9, $\$ 6$; IND. Const. art. 10, $\$ 1(1)$; Mont. Const. art. XII, $\$ 2$; Neb. Const. art. 8, $\$ 2$; Nev. CoNsT. art. $8, \S 2 ;$ S.D. CoNsT. art. XI, $\$ 6$ (legislature required to exempt educational institutions); TENN. CONST. art. 2, \$28; see note 1 supra.

3. The phrase "educational purposes" has not been interpreted to mean that the activities conducted on the land or buildings exempted be indispensable to the educational institution. It is sufficient that the activities are reasonably integrated or re-lated to exempt activities. Sarah Dix Hamlin School v. City of San Francisco, 221 Cal. App. 2d 336, 342, 34 Cal. Rptr. 376, 380 (1963). Property owned by an exempt institution is taxed if characterized by one or more of three factors: (1) it produces income, c.g., property leased to commercial enterprises, see ARIz. REv. STAT. ANN. \$ 42-271 (1956); Conn. Gen. Stat. ANN. \$ 12-81(8) (1958); Fla. Stat. ANn. \$ 196.196(3) (1972); N.Y. Real Prop. TAX LAw \$421(2) (MCKinney 1972); OKLA. Srat. ANN. tit. 18, \$550 (Supp. 1972); TEN. CODE ANN. \$ 67-502 (Supp. 1972); Howard Univ. v. District of Columbia, 155 F.2d 10 (D.C. Cir.), cert. denied, 329 U.S. 739 (1946); People ex rel. Gill v. Trustees of Schools, 364 IIl. 131, 4 N.E.2d 16 (1936); Emerson v. Trustecs of Milton Academy, 185 Matss. 414, 70 N.E. 422 (1904); (2) it is not used for cducational purposes, see State v. Carleton College, 154 Minn. 280, 191 N.W. 400 (1923) (college-owned farm land two miles from campus not used for educational purposes); Trustees of Rutgers Univ, $v$. Piscataway Twp., 134 N.J.L. 85, 88, 46 A.2d 56, 57 (1946) (stadium complex scating 20,000 built for college with an enrollment below 1,700 not a "building actually used for colleges"); but see Yale Univ. v. Town of New Haven, 71 Conn. 316, 42 A. 87 (1899); People ex rel. Goodman v. University of Illinois Found., 388 Ill. 363, 58 N.E.2d 33 (1944); Indiana State Bd. of Tax Comm'rs v. International Bus. Collegc, 145 Ind. Ipp. 353, 251 N.E.2d 39 (1969); Harvard College v. Assessors of Cambridge, I75 Mass. 
is that private educational institutions provide public benefits ${ }^{4}$ and are therefore worthy of public support.

However sound in principle this justification may be, the existing property tax exemption imposes fiscal burdens on municipalities hosting educational institutions. ${ }^{5}$ In an attempt to mitigate this adverse effect of the exemption, municipal governments and universities have entered into a variety of ad hoc "payment in lieu of taxes" agreements. The proposal has also been made that universities pay "service charges" to the municipalities in which they are located for the municipal services they consume.

This Note will discuss the fiscal burden of the property tax exemption and analyze alternative responses to the problem. It will suggest that subsidization of private universities through the property tax exemption should be accompanied by direct state payments to local governments which host educational institutions. In addition, it will discuss valuation difficulties inherent in such a state payments ap-

145, 55 N.E. 844 (1900); City of Hoboken v. Division of Tax Appeals, 134 N.J.L. 594, 49 1.2d 587 (Super. Ct. 1946), aff'd in part, rev'd in part, 136 N.J.L. 328, 55 A.2d 290 (1947); Troy Conference Academy v. Poultney, 115 Vt. 480, 66 A.2d 2 (1949); WasH. REv. CODE ANN. \$ 84.36.050 (Supp. 1972); W. VA. CODE ANN. \$ $11-3-9$ (1966); (3) it competes with local business, see Hilger v. Harding College, Inc., 231 Ark. 686, 331 S.W.2d 851 (1960); Princeton Univ. Press v. Borough of Princeton, 35 N.J. 209, I72 A.2d 420 (1961).

Some states exempt all property of qualified educational institutions regardless of the purpose for which the property is used. See, e.g., Dakota Wesleyan Univ. v. Betts, 47 S.D. 618,201 N.W. 524 (1924).

For a more detailed treatment of individual state statutes and case law, see A. BALK, THE FREE LIST 165.69 (1971); Curtiss, Tax Exemptions of Educational Property in New York, 52 CoRNell L.Q. 551 (1967); Schnell, Real Property Tax Exemptions in Ohio $-A$ Review and Critique, 17 W. RES. L. REv. 824 (1966); Warren, Krattenmaker \& Snyder, Property Tax Exemptions for Charitable, Educational, Religious and Governmental Institutions in Connecticut, 4 CoNN. L. REv. 181 (1971) [hereinafter cited as Property Tax Exemptions]; Note, The Exemption of Educational, Charitable, and Religious Institutions in South Dakota, 11 S. DAkota L. REv. 133 (1966); Note, Charilable Exemptions From Ad Valorem Taxation in Texas, 18 S.W.L.J. 703 (1964); Note, Property Tax Exemption Under Art. VII, Section 3(a) of the Florida Constitution of 1968, 21 U. FlA. L. REv. (1969).

4. See Verde Val School v. County of Yavapai, 90 Ariz. 180, 182, 367 P.2d 223, 225 (1963); Sarah Dix Hamlin School v. City of San Francisco, 221 Cal. App. 2d 336, 341, 34 Cal. Rptr. 376, 379.80 (1963); Yale Univ, v. Town of New Haven, 71 Conn. 316, 332-33, 42 A. 87, 92 (1899); Harvard College v. Assessors of Cambridgc, 175 Mass. $145,148,55$ N.E. 844,846 (1900). See generally People ex rel. Goodman v. University of Illinois Found., 388 Ill. 363, 58 N.E.2d 33 (1944); State v. Carleton College, 154 Minn. 280, 191 N.W. 400 (1923); Ohio North. Univ. v. Tax Comm'r, 21 Ohio App. 2d 113, 255 N.E. $2 \mathrm{~d} \mathrm{297}(1970)$; George Peabody College v. State Bd. of Equalization, 219 Tenn. 123, 407 S.W.2d 443 (1966). A related rationale often offered for the property tax exemption is that it is proper to subsidize institutions providing public benefits which, in the absence of such institutions, would have to be financed by taxation. See A. BALk, supra note 3 , at 22, quoting J. Jensen, Property TAXition in the UNited States (1931).

5. The property tax is the chief source of revenue for municipalities. See Bridges, Past and Future Growth of the Property Tax, in PropertY TAXAion U.S.A. 21 (R. Lindholm ed. 1967). 
proach and will propose a procedure for the implementation of a workable plan.

\section{The Property Tax Exemption and Alternatives}

A property tax exemption is functionally equivalent to inclusion of the property in the tax base and subsidization of the taxpayer in an amount equal to the property's tax bill. ${ }^{\circ}$ One difficulty with distribucing public moneys in this manner is that it is a crude means for ascertaining the proper size of the subsidy. The exemption fixes the subsidy at the level of a university's hypothetical tax bill, that is, the property tax bill that would be due if the university were not exempt from taxation. The appropriate level of subsidy, however, absent redistribution goals, ${ }^{7}$ equals the value of public benefits that the university bestows upon the state and city in which it is located. ${ }^{8}$ Since the hypothetical property tax is a function of factors largely unrelated to the level of educational activity, the property tax relief enjoyed by the university will only accidentally be of comparable magnitude to the benefits it bestows.

Despite these difficulties the property tax exemption has several advantages which recommend its continued use as a mechanism of support. ${ }^{9}$ The most important of these is the freedom afforded private educational institutions from interference by state officials. Further-

6. Sev Property Tax Exemptions, supra note 3, at 292 n.383.

Since taxation is necessarily a process of selection, however, to say that all property not reached by a particular tax enjoys a subsidy is to make a statement so broad as to be meaningless. For example, a tax on cigars cannot be meaningfully said to subsidize nontaxed attomobiles. See Bittker, Churches, Taxes, and the Constitution, 78 YALE L.J. 1285 (1969). Implicit in the conception of an exemption as a subsidy is some a priori notion as to the normal boundaries of the tax. Since the property tax is a complete tax on all real property, an exemption for any form of property (except the public property of the tax base that bears the costs of the exemption) constitutes a subsidy. Hunter, Tax Exemptions-A Subsidy, 8 TAxes 332, 351 (1930).

7. Redistribution goals do not appear to be important considerations for the property tax exemption. See cases cited note 4 supra.

8. Although private universities no doubt confer some benefits which are enjoyed nationally, this Note confines its focus to the relationship between the city and state and the fiscal burden imposed upon the city by the state-enacted exemption.

Federal assistance to higher education is, of course, extensive. For a comprehensive enumeration of the various types of government assistance offered to colleges and students, see A. Balk, supra note 3, at 178-79; Public Affairs Press, Guide to Grants, Lodis and Other Types of Gov't Assistance Available to Students \& Educational. Institutions (1972); The Federal Gov't aNd Higher Education (D. Knight ed. 1960). Furthermore, the federal government indirectly supports cities that host educational institutions, since students are included in the population of that city for revenue sharing purposes. 31 U.S.C. $\$ 1228$ (Supp. II, 1972). The proposed solution suggested in Part II could be modified to take account of federal costs and benefits. See note 68 infra.

9. The advantages and disadvantages of a property tax exemption as a mechanism of public support to universities are discussed more fully below, see pp. 189-90 infra. 
more, whatever advantages or drawbacks there may be to the exemption, as a practical matter it is politically secure.

A more pressing problem stemming from the use of the property tax exemption as a subsidy to private educational institutions, however, is that enjoyment of university-conferred benefits is not limited to city residents. ${ }^{10}$ Such public benefits as art galleries, museums, community health programs, education and welfare programs, professional libraries, and post-secondary educational programs are enjoyed as well by state residents not living within the host city of the institution. As the term "public" suggests, these benefits are analogous to or substitutes for services normally provided by government agencies. ${ }^{11}$ The subsidy, on the other hand, is exacted from a local tax base and is equal to the university's hypothetical local property tax bill. The state generally pays nothing for the benefits enjoyed by state citizens who do not reside in the city. ${ }^{12}$ The university's property tax exemption can thus be viewed as a forced appropriation of municipal revenues-local taxpayers bear the costs of the exemption but have little influence in determining the size of the subsidy. ${ }^{13}$ To the extent city dwellers pay for such benefits wealth is redistributed to state taxpayers living outside the city. This redistribution is in most cases inconsistent

10. See Joint Study Group of the City of New Haven and Yale University, Report

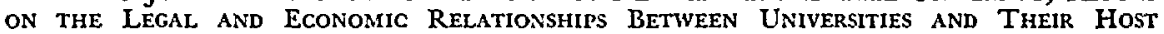
Municipalities V (1972) [hereinafter cited as Yale/NEw Haven Study]; notes 64-67 infra. For a consideration of the difficulties in valuing these and other benefits attributable to a private university, see pp. $194-95$ infra.

11. See pp. 194-95 infra.

12. In certain infrequent instances the state does offer the private university some support either by direct subsidy, see CARNeGie Comm'n on Higher Education, THe CAPITOL AND THE CAMPUS 89-91 (1971), or by some type of state tax exemption (e.g., exemption from the state income tax), see CAL. REv. \& TAX. CodE \$ 2370Id (West Supp. 1973); N.Y. TAX LAw $\$ 601 c$ (McKinney 1966). Since major educational institutions do not generate much income (indeed many, if not most, operate at a deficit or barely break even), the state income tax exemption does not afford a substantial subsidy. See Bowen, Economic Pressures on the Major Private Universities, in JoInT Econonic Committee, 91st Cong., 1st Sess., The Economics and Financing of Higher Education in THE UNITEd States 399 (1969); E. Cheit, The New Depression IN Higher Education (1971). The solution proposed in Part II infra could be modified to take account of state support, see note $\mathbf{5 3}$ infra.

13. Generally the municipality should determine the level of subsidy it wishes to offer the university. Efficient allocation of public goods requires that the political unit be coterminous with the tax base and the welfare area. See generally $R$. MUsGrave, The Theory of Public. Finance 595-621 (1959).

There is some justification, though, for state determination of the level of subsidy if a city is in a position to exercise monopoly powers over the university, as is in fact the case for most universities which have made so substantial a capital investment that relocation to a community willing to offer more adequate support is not a realistic possibility. As a consequence the city might offer less support than it would if it were vigorously competing with other cities for the public benefits attributable to a university. Such market imperfections, however, are no justification for exclusive reliance on the present exemption as a means to subsidize private universities. The present exemption is based not on the level of support a municipality would offer in a fair bargaining situation, but rather on the university's hypothetical local property tax bill. 
with general distributional goals since the central city typically contáins a greater than average concentration of the state's poor. ${ }^{14}$ Furthermore, local government attacks ${ }^{15}$ on the exemption are some indication that the magnitude of the exemption exceeds the subsidy local taxpayers would willingly grant private universities. ${ }^{10}$ Thus the exemption aggravates the fiscal crises facing most cities. ${ }^{17}$

\section{A. Payments in Lieu of Taxes}

Many cities have sought to relieve the excessive fiscal burden imposed by the property tax exemption by requesting payments in lieu of taxes from universities within their jurisdictions. ${ }^{18}$ In recent years ${ }^{19}$ a fair proportion of universities have agreed to make some type of voluntary payment. ${ }^{20}$ These payments, however, have not been based upon the actual burden caused by the city's assumption of the total

14. See Branfman, Cohen \& Trubek, Measuring the Invisible Wall: Land Use Controls and the Residential Patterns of the Poor, 82 YALE L.J. 483, 493, 494 (1973).

15. See note 26 infra.

16. It is theoretically possible, though very unlikely, that the level of subsidy represented by the exemption is less than or equal to the level of subsidy the city would offer the university in a fair, nonmonopoly bargaining situation and that the free benefits the state enjoys are at university expense. The Yale/New Haven Study Group found that the university's hypothetical tax bill exceeded the municipal benefits atuibutable to the university, see note 10 supra. YALE/NEW HAven STUDY I-7, I-12.

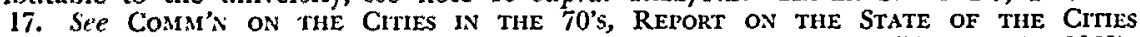
50-5i (1972); THE URbix CRISIS IN AMERICA 135-39 (C. Jones \& L. Hoppe eds. 1969); W. Hirsch, Fiscal pressures on the Central Gities (1971). This concern appears to be the motivation behind a proposed bill drafted by Yale University calling for federal and state payments reimbursing local jurisdictions hosting institutions of higher education. See Yale Daily News, October 19, 1973, at 1, col. 4; proposed bill on file with the Yale Law Journal.

18. Payments in licu of taxes refer to payments made by the university to the city which are not compelled by law and which substitute for property tax payments.

19. Although most agreements have been reached within the last ten years, Harvard University and the Massachusetts Institute of Technology have been making payments to the city of Cambridge since 1928. Under the agreement the two universities make payments for twenty years on any property removed from the tax list after 1928. This agrecment was subsequently renewed in 1948 and annually since 1968. The payments are based on the assessed values of land (not buildings) in the year of purchase. M.I.T. presently pays the city $\$ 229,000$. Harvard pays only $\$ 102,947$ because 11 .I.T. has more recently-acquired property. A. BALK, supra note 3, at 174-75 (reprinting 1948-68 HarvardCambridge Agreement); Interview with Donald Moulton, Assistant Vice President, Community Affairs, Harvard University, at Cambridge, Mass., July 5, 1972; Interview with Ficderick Watriss, Issociatc Treasurer, M.I.T., at Cambridge, Mass., July 5, 1972.

20. In 1969 a study conducted by the American Council of Education found that thirty percent of 318 responding institutions made payments to local governments. See YALI/NEW Haven Study I-4. A more limited study sponsored jointly by Yale University and the city of New Haven found that fifty percent of a select number of colleges (thirty-threc) had made some payment in lieu of taxes. See generally Yale/ NLW HAven Study. This Study was conducted in 1972 for Yale University and the city of New Haven as background for their negotiations to resolve the exemption problem. .llthough eastern and Ivy League schools were emphasized, the schools selected represented all types and sizes of universities and cities throughout the nation. The sample, however, was not chosen randomly: Any college in which there was a known agreement or controversy involving the tax exemption issue was contacted. 
costs of the exemption. ${ }^{21}$ Rather, they have reflected the relative bargaining strengths of the educational institutions and the municipalities, with the latter at a significant disadvantage since the statutory exemption permits the university to refuse to make any payments at all. In fact, it appears that the major reason universities make these payments is to protect the statutory exemption. By making token payments, universities can quiet the tax exemption controversy and avoid legislative action. Generally, however, the threat of taxation has not been very real ${ }^{22}$ and in-lieu payments have consequently been relatively small. ${ }^{23}$

In certain cases the municipality has been able to improve its bargaining position by refusing administrative approval for planned university expansion until an appropriate payments agreement has been reached. Recently, for example, the city of Pittsburgh delayed a major project of the University of Pittsburgh by refusing to make the necessary zoning changes and by not granting certain construction

21. The payments in lieu of taxes alternative could make costs coterminous with benefits on the municipal level. One approach to achieve this goal would be to calculate the actual costs of the university to the city in terms of allocable, e.g., sanitation, and nonallocable, e.g., overhead, costs and to offset the total cost incurred by the reasonable payment the city would offer the university for public bencfits. $A$ second approach, which is functionally equivalent to eliminating the exemption, would be to calculate the university's hypothetical tax bill and offset this bill by the reason* able subsidy the city would offer the university. Problems involved in determining the hypothetical tax bill and reasonable subsidy are discusscd infra. While cach of these alternatives would go far to match costs and benefits on the municipal level, the university would still have to seek state support for benefits which accrue on the state level.

22. See p. 190 infra.

23. Most universities that make a payment in lieu of taxes either pay for a specific service or make a general token payment. Brown University pays Providence for city police at special university events and for the cost of connecting plumbing in its new buildings to existing water works. Interview with Frank Acker, Director of Public Relations, Brown University, and Paul Scheffington, University Counsel, in Providence, R.I., July 7,1972 . Cornell makes annual payments of $\$ 50,000$ to Ithaca for fire protcction and for municipal costs incurred in providing services to each student who is not a permanent resident of the district and who lives in married student housing. Interview with R. Shew, Treasurer's Office, Cornell University, Junc 28, 1972. Dartmouth paid $\$ 100,000$ to Hanover in lieu of taxes in 1967. Since then it has paid about $\$ 550,000$ a year in taxes on its dormitories. Yale/NEw Haven STUdX III-5-III-6. Marquette pays a sewer service charge formulated for exempt institutions by the municipality and based on land assessments, although this arrangement is being challenged in the courts, Milwaukee Catholic Archdiocese v. City of Milwaukee, No. 372-138 (Ciiil Court, County of Milwaukee); Interview with William Carey, Fiscal Coordinator of Milwaukee, June 30, 1972. Purdue pays West Lafayette for sewerage and street lighting. Intervicw with F.A. Dawson, Controller, Purdue University, June 28, 1972. Stanford pays a proportion of the city's waste disposal costs. Interview with Ken Creighton, University Controller, Stanford University, June 16, 1972. The University of Toledo pays Toledo about onethird of the costs of street improvements in tuniversity areas. Interview with Willard Smith, Office of the President, University of Toledo, June 26, 1972. Wesleyan University pays Middletown for water, sewerage and sanitation fees. The university has an "ease-off program" for property which is permanently removed from the tax base. Under the program the university pays taxes on the property at a declining rate for several years after it is removed from the tax lists. YALE/NEw Haven STudy III-15. 
permits. ${ }^{24}$ After lengthy negotiations the university agreed to make annual payments to the city. ${ }^{25}$ Instances of this type of municipal pressure, however, are rare. ${ }^{26}$ Cities fear that the universities may retaliate by curtailing the benefits that they provide to the community. ${ }^{27}$ Nevertheless, as the need for additional municipal revenuc grows, it is reasonable to expect that increasing numbers of municipalities will resort to the manipulation of administrative procedures to exact payments from universities. ${ }^{2 s}$

The serious drawback of payments in lieu of taxes is that the state is not a party to the solution. A payment from the university to the city merely shifts the burden of the state's free benefits from city taxpayers to the university and necessitates university-state negotiations if the university is to recoup its losses.

Furthermore, in the absence of compulsory state standards, the negotiating process between city and university seeking the proper level of payments in lieu of taxes is inevitably distorted by politics and self-interest. Yale University and the city of New Haven attempted such a calculation as background for ongoing negotiations concerning payments in lieu of taxes. Since the university was not legally bound by the results of the calculation, ${ }^{29}$ it could reject or manipulate them for its own purposes. The calculation foreseeably resulted only in dispute, Yale claiming one figure represented its "hypothetical tax bill" and New Haven claiming another. ${ }^{30}$

24. Interview with Dan McFadden, University of Pittsburgh Negotiator, at Cambridge, Mass., July $6,1972$.

25. The agieement called for an annual payment of $\$ 60,000$, subject to adjustment for annual increases or dccreases in the city's operating budget. The payment is said to recompense the city for such services as street maintenance and police and fire protection. The state granted approval because the university is supported in part by state funds. Any property acquired by the university and removed from the tax list in the future will be charged annually for services at the rate of tax prevailing in the ycar of purchase, subject to an annual adjustment as above. Id.

26. Two less dramatic examples of municipal coercion both involved attempted university expansion. Boston recently amended its zoning law to require universities to obtain a "conditional use" permit to expand. Suffolk University agreed to pay a \$10 head tar to the city for the permit. Interview with Ira Jackson, Special Assistant to the Mayor of Boston, at Boston, Mass., July 6, 1972. Recently, Northwestern University bought Evanston a $\$ 31,000$ fire engine in exchange for approval of a zoning variance. The city initially had requested an annual payment in lieu of taxes. Interview with $W$. Kerr, Vice President and Business Manager, Northwestern University, June 28, 1972.

27. Officials in both Boston and Cambridge acknowledged the importance of city cooperation with local universitics. Interview with Ira Jackson, Special Assistant to the Mayor of Boston, at Boston, Mass., July 6, 1972; Interview with Charles Laverty, Assessor of Cambridge, in Cambridge, Mass, July 6, 1972.

28. Recently, the city of New Haven refused to grant permission to Yale University for the construction of new dormitories because of dissatisfaction with Yale's offer as to the amount of municipal revenue the building would generate. New Haven Register, April 3,1973 , at 1 , col. 1 .

29. Conn. GEN. STAt. ANN. \$ $12-81$ (1958) (exempting property used for educational purposes from taxation).

30. See Yale/New Haven Study A-3 (cols. 3 \& 4). 


\section{B. Service Charges}

Frequently suggested as a compromise between repeal and maintenance of the property tax exemption is the so-called "service charge." 31 Implementation of a service charge proposal would allow municipalities to assess charges against universities for the direct services they consume. ${ }^{32}$

Service charges to exempt institutions fail, however, as an effective alternative mechanism for eliminating the burden on municipalities caused by the exemption ${ }^{33}$ because such charges cannot effectively alleviate all of the "forced appropriation" of municipal revenue created by the present property tax exemption. Charging the university for the direct services it consumes merely reduces the existing subsidy to a level equal to that part of the university's hypothetical tax bill that would be designated to pay the nonallocable costs of municipal government. ${ }^{34}$ There is no reason to assume that this reduced subsidy represents the true dollar value of the benefit a private university confers upon a municipality.

Furthermore, even if the reduced subsidy (the subsidy remaining after imposition of service charges) did equal the value of the benefits conferred upon the municipality, the service charge approach, like the payment in lieu of taxes approach, does not involve the state in financing its share of the public benefits generated by the university. Both approaches serve merely to shift the cost of the state's free benefits from the city to the university.

\section{Eliminating the Exemption}

Perhaps the simplest solution to the problems created by the property tax exemption would be to eliminate the exemption ${ }^{35}$ and

31. Service or user charges refer to charges levied against residents for allocable municipal services consumed, e.g., electricity, water, sewerage and sanitation. Nonallocable costs are the general costs of city government, e.g., the mayor's salary, which cannot be allocated to specific users. See YaLE/NEw Haven STUd IV.

32. Recently, for example, Connecticut's Commission on Tax Reform suggested that tax-exempt properties be charged for the costs of supplying water, sewerage and sanitation services. Governor's CoMm'N ON TAX REFORM, LOCAL GOVERNMENT SCHOOLS AND Property 30 (1972). See also A. Balk, supra note 3, at 136-37.

33. User charges levied on a city-wide basis would, however, lead to a more cfficient allocation of resources. Municipal services are part of the cost of an activity and ideally should be reflected in the price of the goods or services that activity produces. Nonallocable costs of city government could be financed by a method that served distributional goals-a progressive municipal income tax, for example. Thus service charges to finance direct costs and a progressive taxing mechanism to finance indirect costs may be a viable alternative system of financing municipal government.

34. For example, assume that the university's hypothetical tax bill is $\$ 100$ and that it consumes $\$ 40$ in direct services. Charging the university for direct services it consumes fixes the level of subsidy at $\$ 60$.

35. The commentators agree that the case law prior to Walz v. Tax Comm'n, 397 U.S. $664(1970)$, suggests no "free exercise" obstacle to state repeal of the property 
allow the city and state to determine jointly the appropriate level and apportionment of public support. The city and state would simply make direct payments to the university ${ }^{36}$ and any inequitable municipal burden attributable to the property tax exemption would be eliminated. The political effectiveness of the university, of course, would be an important factor in determining what that level of support would be. ${ }^{37}$ Yet eliminating the exemption and replacing it with direct payments could lead to a subsidy based directly on the city's and state's perceptions of the benefit they receive from the university ${ }^{38}$ rather than on the university's hypothetical tax bill. ${ }^{39}$ In addition, direct subsidies would make visible the actual financial relationship between taxpayers and the supported institution, ${ }^{40}$ thus facilitating periodic review ${ }^{41}$ of the public subsidy and periodic changes $^{42}$ if taxpayers should so demand.

On the other hand, the property tax exemption as a mechanism for providing a public subsidy to private universities has been justified as superior to direct payments because it frees the university from political interference via budgetary control, ${ }^{43}$ thereby encouraging diversity and experimentation in the public-supported sector. ${ }^{44}$ Furthermore, the exemption insures continuity of public support, thus facilitating long-range planning. These arguments are buttressed by general principles of academic freedom. Educational institutions should be free from direct governmental control to enable them to fulfill their role as independent critics of government action. ${ }^{45}$

tax cxemption for church-supported eleemosynary institutions. See Bittker, supra note 6, at 1305 n.70; Property Tax Exemptions, supra note 3, at 204-06. Walz, however, contains dicta to the effect that elimination of the exemption "would tend to expand the involvement of government" in the activities of religious institutions. 397 U.S. at 674. Walz also strongly hints that replacement of the exemption with direct subsidies to religious institutions would unconstitutionally involve the state in sectarian affairs. $I d$. at 675 . The exemption may thus be the only way to support church-sponsored universities.

36. See Property Tax Exemptions, supra note 3, at 299.

37. See O. Eckstein, Public Finance 33 (2d ed. 1967).

38. See W. Hirsch, The Economics of State and Local Governments 217-54 (1970).

39. See Property Tax Exemptions, supra note 3, at 303.

40. See id. at 301 .

41. See Advisory Comm'N on Intergovernmental, Relations, The Role of the States in Strengthening the Prolerty Tax 84-85 (1963).

12. O'Bannon, Payments from Tax Exempt Property, in Property Taxation, USA, supra note 5 , at $187,207$.

43. See Kendrick, Property Tax Exemptions and Exemption Policies, 51 NaT' Tax Ass'N CONF. Procend. 84, 88 (1959).

14. Slitor, Tax Incentives and Urban Blight, in TAX INST. OF AMERICA, TAx INCLNTIVEs 257, 258 (1971); Stone, Federal Tax Support of Charities and Other Exempt Institutions: The Need for a National Policy, 1968 So. CAL. TAX Inst. 27, 42. Implicit in this contention is the notion that the exempt institution is somehow more worthy of public support than other institutions that must compete for the public dollar on a year-toyear basis. See Property Tax Exemptions, supra note 3, at 296-97.

45. Intervicw with John Ecklund, Treasurer, Yale University, in New Haven, Conn., June 28, 1972. See also Hughes, Tax Exemptions, 13 TenN. L. Rev. 79, 84 (1935); 
Whatever the merit of arguments for and against the exemption as a mechanism of public support, as a practical matter the property tax exemption is politically secure. To date, no state has seriously considered repealing it, at least with regard to educational institutions. Recent developments indicate its continued support among legislators. ${ }^{46}$ In New York, for example, after debate over the financial burden on municipalities created by the exemption, the state legislature refused to tax or impose service charges on educational institutions, ${ }^{47}$ although it did allow municipalities to assess service charges on other exempt institutions. ${ }^{48}$ Several city administrators have stated that the improbability of repeal of the exemption was one factor that led them to request payments in lieu of taxes. ${ }^{49}$

\section{State Payments to Municipalities}

Since repeal of the property tax exemption is not at present a realistic political possibility, solution of the problems created by the exemption must be found in an alternative structure for provision of public subsidies to private education. One such structure, set forth later in this Note, involves direct state payments to the city in which a private university is located. ${ }^{\mathbf{5 0}}$ The property tax exemption would still subsidize the universities, but the subsidy would be offset in part by the direct state payments.

This structure responds forthrightly to the most serious problem the exemption creates-receipt of benefits by state citizens not residing in the city at the expense of municipal taxpayers. State payments

Kendrick, supra note 43 , at 84,88 . Certain commentators have argued that long-term appropriations can prevent state interference with the exempt institutions' activitic. See Property Tax Exemptions, supra note 3, at 297.

46. In Maryland a bill to tax all commercially-rented university property was dcfeated. Interview with Charles Quant, University Counsel of Johns Hopkins University, June 27, 1972. In Wisconsin the state legislature refused to enact a proposal that re: quired exempt organizations to submit an inventory of property to justify their cxemptions. Letter from William C. Carey, Fiscal Coordinator of Milwaukec, to the Yale Law Journal, July 10, 1972. Minnesota amended its, constitution in 1970 to allow the legislature to limit property tax exemptions but educational institutions wcre cxcepted. Minn. Consr. art. 9, \$1, as amended Nov. 30, 1970.

47. Churches and certain charitable institutions were also cxempted from possible municipal service charges. N.Y. REAL Prop. Law $\$ 21$ (McKinney Supp. 1972).

48. Id. $\$ 498$.

49. Interview with Charles Laverty, Assessor of Cambridge, in Cambridge, Massachusetts, July 6, 1972; Interview with Sheldon Lynn, Assistant Director of City Planning, City of New Haven, July 10, 1972.

50. State payments to cities hosting educational institutions would present no "estab. lishment clause" problem so long as the state payments formula did not single out church-sponsored institutions for support. Provision of payments to any city hosting a university should satisfy First Amendment strictures. See Everson v. Board of Educ., 330 U.S. I (1946). State payments to cities hosting educational institutions, in effect, merely expand the tax base from which the costs of the exemption are borne. $C f$. Walz v. Tax Comm'n, 397 U.S. 664, 673 (1970). 
to the city would reflect the value of these hitherto free benefits conferred on state citizens by a university. Such a plan would serve the interests of academic freedom by leaving the tax exemption intact. Moreover, preservation of the tax exemption should defuse the political opposition of powerful interest groups strongly committed to its preservation, e.g., churches, charitable institutions and universities.

\section{Implementing the State Payments Approach}

Although the state payments approach is an acceptable solution to the problem of the inequitable fiscal burden imposed upon cities by the property tax exemption, it poses practical difficulties of its own. Foremost among these is the problem of ascertaining the proper size of state payments to local governments. The difference between the present level of public support as determined by the property tax exemption and the level of support the city would offer in a fair bargaining situation might serve as the measure of state payments to municipalities. This approach avoids the disadvantage of establishing the municipal share of the public subsidy at a level independent of the actual benefits conferred by the university upon the municipality; the city "pays" the university only to the extent that it has benefited from the university's presence. Unfortunately, determining how much a given municipality would "pay" for the benefits conferred by a particular university is practically impossible. The hypothetical market value of such factors as the prestige of hosting an educational institution, the impact of the university on the availability of professional services, the contribution of the university's educated population to local government, and other tangible and intangible benefits attributable to a university is simply not subject to meaningful quantification.

The ratio of university-related benefits conferred upon the state to those conferred upon the host city, however, is a sound and workable organizing principle for determining the size of state payments to municipalities. The size of state payments under this principle would be a function of three variables: the amount of the existing subsidy given the university by the property tax exemption, the benefits accruing to the city and the benefits accruing to the state. ${ }^{51}$ Once the size of the existing property tax exemption subsidy is as-

51. The total subsidy would remain fixed at the level of the university's hypothetical tax bill. Thus, there is no guarantee that this remaining state subsidy would equal the amount that the state would offer under ideal market conditions. Cf. note 6 supra. 
certained, the state's share of the total subsidy would be proportionately equal to its share of the total benefits. ${ }^{52}$ The amount the state should pay to the city, therefore, is equal to its portion of the total subsidy. ${ }^{53}$

Under this principle, of course, the level of municipal subsidy to private universities may not equal the level the city would offer the university under ideal market conditions. The advantage of a principle employing a ratio, however, is that problems of valuation are significantly less troublesome. A ratio minimizes certain errors of valuation, since errors which occur are likely to be reflected in both the state and municipal valuations and thus by means of the ratio will be somewhat neutralized. Furthermore, although this approach is not designed to equalize perfectly the subsidy granted and the benefits received on the municipal level, it causes the costs of the subsidy to be borne proportionally by both the state and city; the political unit that enjoys the greater proportion of public benefits will bear the greater burden of public support.

\section{A. Determining the Hypothetical Tax Bill}

The first step in calculating state payments under the ratio principle involves the measurement of the present level of the public sub. sidy enjoyed by private universities, i.e., the university's hypothetical property tax bill. The present property tax formula-the tax rate multiplied by a percentage of the assessed value of property-presents a major difficulty in calculating this hypothetical tax bill. Universities, relying upon the property tax exemption, have probably acquired more land and built more elaborate structures than they would have if faced with the annual cost of a property tax. ${ }^{54}$ Calculating the hypothetical tax bill according to property valuations will produce a figure higher than the university would have paid if it had never been exempt and it thus overstates the revenue loss attributable to the property tax exemption.

52. See note 64 infra.

53. Some states at present subsidize private universities by means of tax exemptions or by direct subsidy. See note 12 supra. As this simple example illustrates, the ratio principle would still be applicable. Assume that total support of the university is $\$ 20$ $(\$ 15$ from the city via the property tax exemption and $\$ 5$ direct support from the state) and that total benefits attributable to the university are valued at $\$ 20$ (\$15 going to the state and $\$ 5$ going to the city). Since the state enjoys 75 percent of the benefits, according to the ratio principle it should bear 75 percent of the costs or \$15. Consequently, the state payment should be $\$ 10$.

54. For example, Yale University's Beinecke Rare Book Library was constructed on a university walking plaza; if that elaborate structure had been subject to taxation, it may not have been built and the rare books may have been located in existing library facilities. Interview with Robert Leone, Associate Director, Institute of Social and Policy Studies, Yale University, April 10, 1973. 
An alternative procedure for measuring the university's tax bill was developed by the study group sponsored by Yale University and the city of New Haven.5s It involves the use of a "mark-up"-the ratio of allocable municipal services consumed by a piece of property to that property's tax bill. For example, if the average parcel of real estate within a city receives $\$ 10$ in direct services and pays $\$ 40$ in taxes, the average mark-up is 4 . For every $\$ 1$ paid. for allocable municipal services, $\$ 3$ are paid for nonallocable municipal services. ${ }^{50}$ If the value of allocable municipal services consumed by the university is calculated, that value can be multiplied by the mark-up to determine the university's hypothetical tax bill. ${ }^{57}$

The relationship between allocable municipal services consumed by a piece of property and its tax bill is, in part, a function of whether it is used for industrial, commercial or residential purposes, ${ }^{\text {s\$ }}$ a fact which the calculation of the university's hypothetical tax bill should take into account. ${ }^{50}$ The amount of allocable municipal services supplied to each classification should be multiplied by the adjusted mark-up for that classification. ${ }^{60}$ The hypothetical tax

55. Yale/New Haven Study N-1 to N-4.

56. Assume, for example, that "New City"s" revenue from taxes is $\$ 150$ and that it delivers $\$ 50$ in direct services, $\$ 20$ of which is consumed by New City's only exempt institution, City College. Under present law the average mark-up for the city is 5 , because taxpayers pay $\$ 150$ in taxes and receive $\$ 30$ in services (for every $\$ 1$ in direct services consumed, a $\mathrm{New}$ (ity taxpayer pays on the average $S_{5} \mathrm{~s}$ in taxes).

If the university were taxed, the tax rate throughout the city would be lower, all other things being equal. Consequently, the mark-up will have to be adjusted to reflect the assumption that the university is being taxed. In New City, if the university were also taxed, assuming the same total revenue, the average mark-up for the city would be 3 since taxpayers would then receive $\$ 50$ in services and pay $\$ 150$ in taxes.

57 . In the New City example, supra note 56, the university tax bill would be $\$ 20$ (direct services to City College) $\times 3$ (adjusted average mark-up for New City) $=\$ 60$.

58. Property within New City can be classified by land use; each classification's share of direct services and tax bill is shown below:

$\begin{array}{lccc} & \text { Direct Services } & \text { Mark- } u p & \text { Tax } \\ \text { Industrial } & 10 & 6 & 60 \\ \text { Commercial } & 10 & 5 & 50 \\ \text { Residential } & 10 & 4 & 40 \\ \text { Exempt } & 20 & 0 & 0 \\ \text { Total } & \frac{50}{150}\end{array}$

59. In New City one can hypothesize that direct services to the various classifications of property owned by City College are, respectively:

$\begin{array}{lr}\text { Industrial } & \mathbf{5} \\ \text { Commercial } & \mathbf{5} \\ \text { Residential } & 10\end{array}$

60. The mark-up for each classification would be adjusted for the fact that City College's land is not included in the tax base; its inclusion would reduce the hypothetical overall rate, assuming expenditures remain constant:

$\begin{array}{lccc} & \text { Direct Services } & \text { Tax* } & \begin{array}{c}\text { Adjusted } \\ \text { Mark-up }\end{array} \\ \text { Industrial } & 15(10+5) & 60 & 4 \\ \text { Commercial } & 15(10+5) & 50 & 3.3 \\ \text { Residential } & 20(10+10) & \underline{40} & 2 \\ \text { Total } & 50 & 150 & \end{array}$


bill is thus equal to the sum of the tax bills for the various classifications. ${ }^{61}$

The major difficulty with the mark-up approach lies in determining what share of allocable municipal services are consumed by the university and by other classifications of land users. The Yale/New Haven Study Group found that city departments generally possessed sufficient information to devise reasonable allocation methods and that these methods could be refined by controlling for possible biases; if allocations were to become a regular procedure, as a state payments approach would require, city departments could keep the records necessary to make allocations more easily and more accurately. ${ }^{62}$ Under such circumstances the mark-up should prove to be a realistic and workable procedure for measuring the university's hypothetical tax bill.

\section{B. Determining the Flow of Public Benefits Attributable to Universities}

After the present property tax exemption subsidy to a private university is measured, the next step is to ascertain how benefits conferred by that university are apportioned between city and state. ${ }^{63}$ Such a calculation requires the identification of university activities which generate public benefits, the value of those benefits and the political units which enjoy them. The procedures adopted by

61. For City College:

Industrial
Commercial
Residential
Total Tax Bill

$\begin{array}{ccc}\cdot & \text { Adjusted } & \\ \text { Direct Services } & \text { Mark-up } & \text { Tax } \\ 5 & 4 & 20 \\ 5 & 3.3 & 16.5 \\ 10 & 2 & 20 \\ & & \frac{56.5}{56}\end{array}$

62. Yale/New Haven Study IV-10. For example, the Yale/New Haven Study Group allocated direct police costs to the various classes of land users by superimposing a land use map over a police department map which identified the number of crimes reported on relatively small plots of land. Thus it is possible to determine the number of reported crimes committed on commercial, industrial, residential, Yale, and "other" property. Direct police costs were allocated among the various land users in the same proportion as reported criminal activity. See YALE/NEw HAVEN STUDY IV-18 to -21. This approach assumes that the services provided in response to each call were equally costly.

63. Different parts of a state may actually receive proportionally more benefits than other parts, e.g., towns and communities that enjoy easy access to the university museums and art galleries as opposed to towns and communities at a much grcater distance. In terms of matching costs and benefits, the adjacent communities should actually bear a greater percentage of the costs. The state is treated here as a single entity because in most cases the transaction costs of allocating benefits to specific areas in the state will exceed any efficiency gain in matching costs and benefits more accurately. Nevertheless, such a calculation is possible and in certain cases direct payments by surrounding communities may be appropriate. 
the Yale/New Haven Study Group are illustrative of the methods that can be used to make such a calculation.

The Yale/New Haven Study Group limited its valuation of university-conferred benefits to those which substitute for or are analogous to services normally provided by government agencies. ${ }^{64}$ The benefits were allocated between the city and state on the basis of which level of government could be expected to provide those benctits, or their analogues, in the university's absence..$^{6.5}$ The Study Group allocated benefits attributable to post-secondary educational programs, professional libraries and mental health programs to the state; benefits attributable to the university art gallery, the museum of natural history, and community health, education and welfare programs were allocated to the city. The value of these benefits was senerally calculated at the cost to Yale ${ }^{66}$ of providing them less all outside revenue, e.g., federal and state grants and admission fees. ${ }^{67}$ The Yale/New Haven Study illustrates that procedures can be adopted to produce, at reasonable cost, a fairly accurate valuation of benefits conferred by the university on city and state. Once these benefits have been determined, the ratio of city benefits to state benefits may be used to determine the state payment to the city. ${ }^{68}$

64. No attempt was made to calculate the value of those benefits flowing from the lact that colleges, especially the larger universities, employ many individuals, consume local goods and services and attract out-of-state purchasers. Local commerce and industry also provide these benefits and are fully taxed on their property. It is reasonable to focus on those benefits that are substitutes for or analogous to public benefits provided by government since it is those benefits that are said to justify the exemption. Sec note 4 supra.

65. The determination of which governmental unit would probably provide each type of benefit was somewhat arbitrary. More sophisticated allocations, however, are possible. For example, although an art gallery or museum may be most frequently visited by city residents and school children, state residents not living in the city also benefit from these facilities. Thus, a portion of the total benefit attributable to the museum or art gallery should be allocated to the state.

66. The benefit derived from post-secondary education programs at Yale for Connecticut undergraduate and graduate students was based on the average state subsidy to state colleges. The benefit derived from the training of doctors and lawyers who would settle in Connecticut was based on the university's actual expense less all outside revenue. Yale/New H.aven Study V-6.

67. Since the benefits provided by the university are substitutes for or analogues of public goods, market prices for these benefits do not exist. The university's cost basis of its inputs was used as a proxy for the market price of services.

68. This Note has focused on the relationship between the city and state, although the nation also benefits from the operation of educational institutions. See note 7 supra.

While the problems of valuation would become exceedingly complex, the federal government could be added to each side of the equation. This addition might scale down the municipal and state subsidies of private universities in relation to the proportion of university benefits received and subsidies granted by the federal government. 


\section{Conclusion}

The private university's property tax exemption in effect forces local taxpayers to pay for those public benefits conferred by the university upon state citizens not residing in the city. The present alternative to the exemption-payments in lieu of taxes-and a frequently suggested alternative-service charges-prove to be inadequate solutions to this problem. Repeal of the exemption is not a realistic political possibility. State payments to the cities hosting educational institutions can, however, deal with this problem of forcing local taxpayers to pay for benefits conferred upon the state. While there are valuation' difficulties in the state payments approach, they are not so serious as to make a state payments approach unworkable.

Furthermore, the valuations suggested here may reveal, in certain cases, that university benefits far exceed public support, suggesting that university support should be supplemented. Or the valuations may indicate that the exemption significantly oversupports the university, suggesting that the exemption mechanism itself should be altered. In the latter case, perhaps the data these valuations would offer might shake the existing security of the exemption..$^{60}$

69. The controversy surrounding the property tax exemption in many cities has focused on universities because they own significantly more land and consume substantially more municipal services than most exempt institutions. Nevertheless, the analysis and solution developed in this Note are applicable to all property of taxexempt institutions whose benefits are conferred on both the state and local level. 